原著

音刺激によるヒト前庭性誘発筋原性反応

一温度眼振反応との解離例に関する検討一

\author{
將積日出夫・長崎 正男・安村佐都紀 \\ 張 瑞麗・赤荻 勝一・伊東 宗治・渡辺 行雄
}

\title{
Vestibular Evoked Myogenic Potential among Dizzy Patients
}

\author{
Hideo Shojaku, Masao Nagasaki, Satsuki Yasumura, \\ Rui Li Zhang, Katsuichi Akaogi, Muneharu Ito, Yukio Watanabe \\ Department of Otolaryngology, Toyama Medical and Pharmaceutical University
}

Click-evoked myogenic potential of cervical muscle to intense clicks shows a characteristic short-latency positivity-negativity, and it is thought to be due to vestibulo-collic reflex. In this study, in order to evaluate the origin, myogenic potential and caloric response were compared among 4 dizzy patients.

In the first two case (right delayed endolymphatic hydrops and right acoustic tumor), the myogenic potential to the click of affected ear was normal, while caloric testing revealed a high CP \% (71\% and 53\%). In the remaining two cases (right Meniere's disease and left acoustic tumor), myogenic response was abnormal compared with low CP \% (21\% and 29\%).

These discrepancies between myogenic potential and caloric response suggest that click-evoked short-latency myogenic potential may be dependent on lateral semicircular canal function.

Key words: click-evoked potential, neck, myogenic potential, origin

\section{はじめに}

1992年オーストラリアの Colebatch と Halma$\mathrm{gyi}^{11)}$ は, 強大音により誘発される胸鎖乳突筋筋 電図反応が前庭神経切断術後に消失したことか ら，この反応が前庭頸反射を反映するものと考 光, Vestibular Evoked Myogenic Potentials $(\mathrm{VEMP})^{2)}$ と命名した。そこで私共は，先に 正常耳, 高度難聴耳括よび前庭機能高度低下耳を 対象として VEMP 反応を記録した。その結果, 刺激開始から $30 \mathrm{msec}$ 以内に刺激側之同側性に

富山医科薬科大学耳鼻咽喉科学教室
現れる 2 相性の波形からなり，その波形の出現の 有無から蝸牛ではなく硫酸ストレプトマイシン (SM) により障害をらける末梢前庭器に由来する 反応であることを明らかとした。本研究では，温 度眼振反応と VEMP 反応の解離が観察された内 耳ならびに後迷路性障害例を呈示して VEMP の 末梢前庭器内の起源について考察した。

\section{方法}

検査方法は先の論文 ${ }^{3)}$ に詳細に記載したので, 本研究では簡単に紹介した。へッドホーンから片 側音刺激を行い，対側耳にはマスキング（-30 $\mathrm{dBnHL})$ を与えた。刺激音はクリック音（105 
dBnHL 以下）を用い，加算回数は500回とした。 電極は，左右胸鎖乳突筋上のそれぞれ胸鎖乳突筋 吻尾側 2 分の 1 , 胸骨頭の起始部上と前額部に接 着した。被験者に対して，検査中は坐位にて頸部 を捻転するよう指示をした。VEMP 反応は同側 性2) 4)であるので，本研究では右耳刺激では左 頸部捻転時のみ，左耳刺激では右頸部捻転時のみ の誘発反応結果を示した。

正常 20 人 40 耳に $105 \mathrm{dBnHL}$ のクリック音を聴 取させた場合には，刺激開始から $30 \mathrm{msec}$ 以内 に陽性波の後で陰性波が続く，2相性の誘発波形 が記録される。前者を $\mathrm{P} 1$ ，後者を $\mathrm{N} 1$ とすると， 正常20人40耳での P1 潜時は平均 $13.6 \mathrm{msec}$ (SD $1.90 \mathrm{msec}$ ), $\mathrm{N} 1$ 潜時は $23.0 \mathrm{msec}$ (SD 2.87 $\mathrm{msec}$ )であり, P1， N1 潜時の左右差の平均はそ れぞれ $0.62 \mathrm{msec}$ (SD $1.35 \mathrm{msec)}, 0.01 \mathrm{msec}$ （1.58 msec）と計算された。をた，P1-N1 波頂 間振幅は平均 $98.2 \mu \mathrm{V}(\mathrm{SD} 35.9 \mu \mathrm{V})$ で，波頂間 振幅の左右比の平均 1.29 (SD 0.82）であった。 したがって, 各パラメータの正常範囲は P1 潜時 が $10.4 \mathrm{msec}$ から $16.8 \mathrm{msec}, \mathrm{N} 1$ 潜時が 17.3 msec から $28.7 \mathrm{msec}, P 1$ 潜時の左右差が 3.17 $\mathrm{msec}$ 以下, $\mathrm{N} 1$ 潜時の左右差が $3.33 \mathrm{msec}$ 以下, $\mathrm{P} 1-\mathrm{N} 1$ 波頂間振幅が $26.3 \mu \mathrm{V}$ から $170 \mu \mathrm{V}, \mathrm{P} 1-\mathrm{N}$ 1 波頂間振幅の左右比が2.9倍以上と計算された。

検査対象は, 内耳性障害症例 2 例 (通発性内り ンパ水腫, メニエール病）扣よび後迷路性障害症 例 2 例（聴神経腫瘍）とした。

\section{結 果}

表 1 K対象 4 症例の神経耳科学的検査結果を示 した。いずれも平衡機能検査時には自発眼振を認 めず，OKN， ETT，FFS で明らかな異常を認め なかった。以下, 個々の症例について VEMP 反 応と CP\%の関係を検討した。

（1）内耳性障害症例での反応

図 1 k温度刺激検查で $\mathrm{CP} \%$ が71\% と高度 $\mathrm{CP}$ を示した右同側性遅発性内リンパ水腫症例（症例 1）のVEMP 反応を示した。患側刺激では，P 1, N1 波頂潜時はそれぞれ $16.1 \mathrm{msec}, 22.1 \mathrm{msec}$, 一方，健常耳側刺激ではそれぞれ $13.4 \mathrm{msec，}$ $19.9 \mathrm{msec}$ であり，いずれる正常範囲内であっ た。また $\mathrm{P} 1-\mathrm{N} 1$ 波頂間振幅は, 健常耳側刺激で

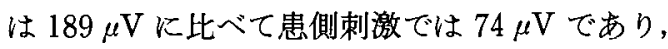
健常耳側は患側の約 2.5 倍と正常範囲内であった。
表 1 神释耳科学的検查結果一覧

\begin{tabular}{|c|c|c|c|c|}
\hline & 症例 1 & 症例2 & 症例3 & 症例4 \\
\hline 年齢 & 28 & 38 & 70 & 38 \\
\hline 性別 & 男 & 男 & 女 & 男 \\
\hline 患側 & 右 & 五 & 右 & 左 \\
\hline 病名 & DEH & 入病 & AT & AT \\
\hline 自発眼振 & なし & なし & なし & なし \\
\hline $\mathrm{CP}$ & 右 & 右 & 右 & 左 \\
\hline $\mathrm{CP} \%$ & $71 \%$ & $21 \%$ & $48 \%$ & $29 \%$ \\
\hline OKN & 正常 & 正常 & 正常 & 正常 \\
\hline ETT & smooth & smooth & smooth & smooth \\
\hline FFS & $(-)$ & $(-)$ & $(-)$ & $(-)$ \\
\hline PTA 右 & $131 \mathrm{~dB}$ & $48 \mathrm{~dB}$ & $17 \mathrm{~dB}$ & $3 \mathrm{~dB}$ \\
\hline 左 & $16 \mathrm{~dB}$ & $0 \mathrm{~dB}$ & $6 \mathrm{~dB}$ & $25 \mathrm{~dB}$ \\
\hline$A B R$ & 未施行 & 末施行 & 右無反応 & $\begin{array}{l}\text { 左 I-V間 } \\
\text { 潜時延長 }\end{array}$ \\
\hline
\end{tabular}

DEH : 遅発性内リンパ水腫 メ病: メニエール病 AT : 聴神経腫瘍 PTA : 平均純音聴カレベル

一方, 温度刺激検查で $\mathrm{CP} \%$ が $21 \%$ と軽度の CP がみられた右メニェール病確実例（症例 2） では，VEMP 反応は患側のみで異常を示した（図 2 )。健側刺激では，P1，N1 波頂潜時はそれぞ

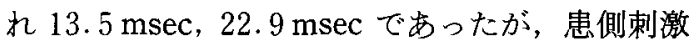
では誘発筋電図反応は再現性なく、汪とんど認め られなかった。

（2）後迷路性障害症例での反応

温度刺激検查で $\mathrm{CP} \%$ が $48 \%$ と高度 $\mathrm{CP}$ がみら れ，造影 MRI にて内耳道内に腫瘍影（図 3 ）が 認められた右聴神経腫瘍症例（症例 3 ）では, VEMP 反応では正常であった（図 4 ）。患側刺激 では，P1，N1 波頂潜時はそれぞれ $13.4 \mathrm{msec，}$ $23.2 \mathrm{msec}$ ，一方健側刺激ではそれぞれ 12.1 $\mathrm{msec}, 23.0 \mathrm{msec}$ であった。両側とも刺激開始か ら $30 \mathrm{msec}$ 以内に 2 相性の誘発波形が得られた。 また P1-N1 波頂間振幅は, 健常耳側刺激では 65

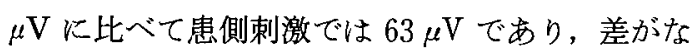
かった。

次に左㯖神経腫瘍症例（症例 4 ）では, 温度眼 振反応で CP\%は $29 \%$ と軽度 CP がみられたが， VEMPでは明らかな潜時の遅延が認められた（図 5 )。

患側刺激では，P1，N1 波頂潜時はそれぞれ $18.0 \mathrm{msec}, 31.5 \mathrm{msec}$ ，一方，健常耳側刺激では

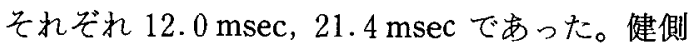


A

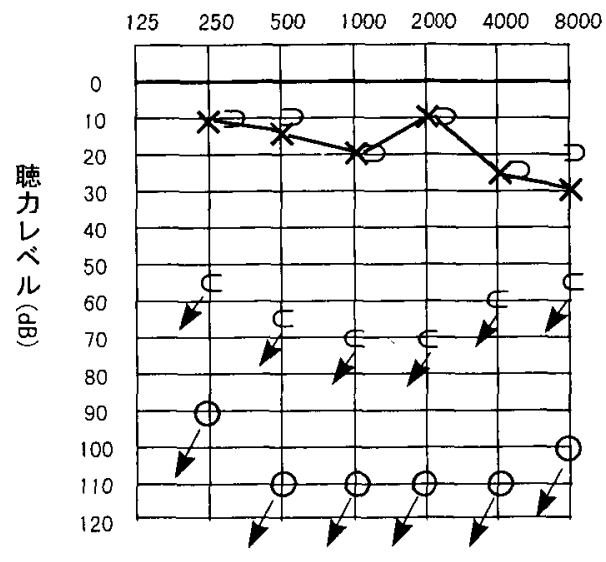

B

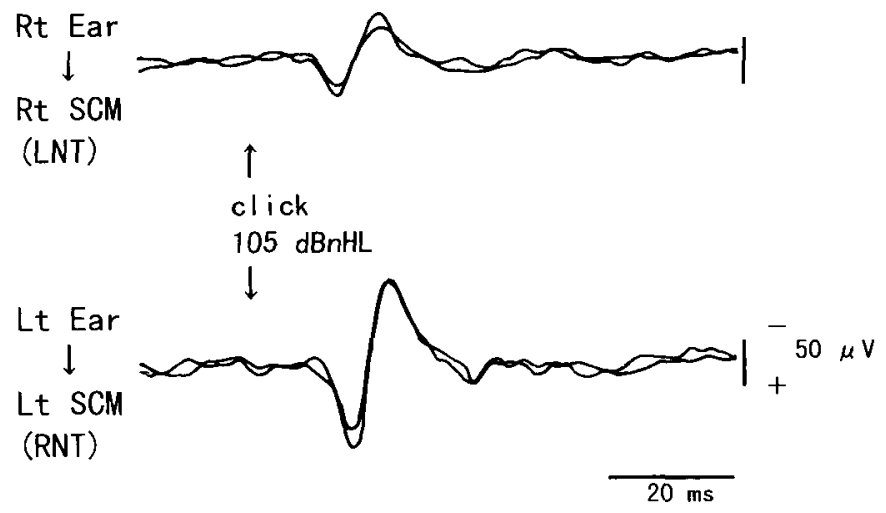

SCM：胸鎖乳突筋

图 1 右遅発珄内リンパ氷腫昰例の VEMP 左図は純音聴力検查，右図は胸鎖乳突筋誘発筋電図反応結果を示した。頸部捻転時の胸鎖乳突筋誘発筋電 図变化。上段が右耳刺激で左頸烩転時の右胸鎖乳突筋皮膚表面電極道出記録, 下段が左耳刺激で右頸捻転 時の左胸鎖乳突筋皮唐表面電極導出記録を示した。各記録右横の䋛線は $50 \mu \mathrm{V}$ の校正，図右下の横線は $20 \mathrm{msec} の$ 校正を示した。

A

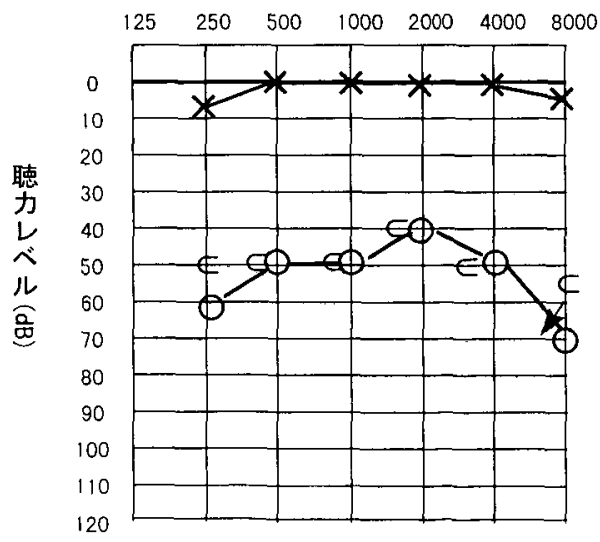

B

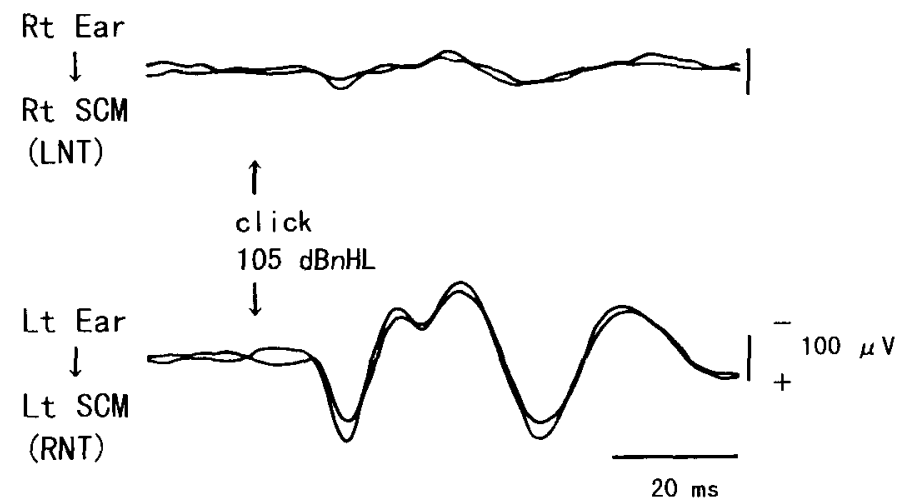

SCH : 胸鎖乳突筋

記録右横の縦線は $100 \mu \mathrm{V}$ の校正。

に比べて患側では $\mathrm{P} 1 ， \mathrm{~N} 1$ 波頂潜時がそれぞれ $5.8 \mathrm{msec}, 10.1 \mathrm{msec}$ と明らかな異常な遅延がみ られた。P1-N1 波頂間振幅は，健常耳側刺激で
は $90 \mu \mathrm{V}$ に比べて患側刺激では $44 \mu \mathrm{V}$ であり， 患側は健常側の約1/2であった。 


\section{考察}

温度刺激検査時, 外側半規管が垂直となる最適 頭位である坐位 60 度後屈位にて行われる5)。した がって, 冷温交互温度刺激検査により得られた眼 振反応上り計算される $\mathrm{CP} \%$ は，外側半規管の機 能を判定するものと一般的に考号られている。本 研究に敃いて温度眼振反応の $\mathrm{CP} \%$ の程度と VEMP 反応の間に解離例が認められたことは, VEMP 反応が CP\% で評価される外側半規管機 能をそのまま反映するものではなく，むしろ外側

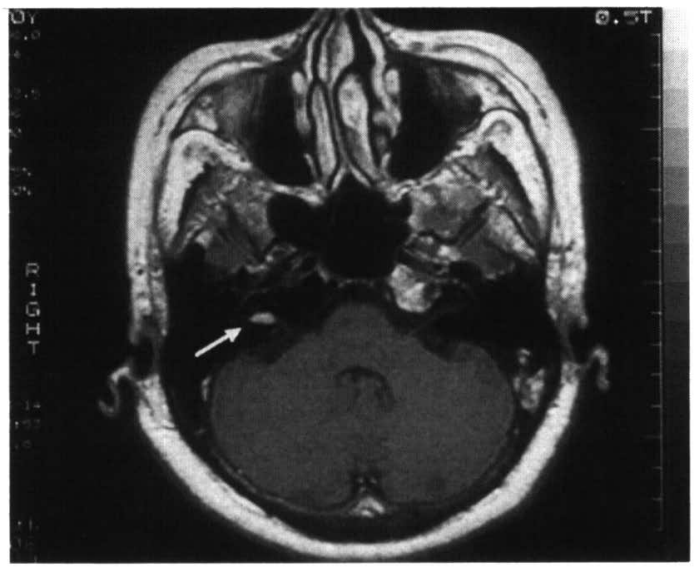

図 3 右聴神経腫瘍症例の MRI 右内耳道内に Gd-DTPA にて増強される $1 \mathrm{~cm}$ 弱の腫瑒陰影がみられた。
半規管以外の末梢前庭器官の機能をみている可能 性が強く示唆される。

今回の検査結果と同様の解離現象は, これまで 外後頭隆起反応において報告され,ている。Townsend と Cody ${ }^{6)}$ は, $1 \mathrm{kHz}$ の tone burst 刺激を 用いた外後頭隆起一鼻根部間の基準導出（外後頭 隆起反応）により，(1)温度眼振反応が正常な左同 側性遅発性内リンパ水腫症例で左側のみで誘発反 応は消失, (2)温度眼振反応が正常の両側内リンパ 水腫症例で誘発反応は両側とも消失したことを指 摘した。さらに, 内リンパ水腫に対して球形囊切 開術を施行した症例では, 術後の温度眼振反応は 正常であったが，誘発反応は消失したことなどか ら音刺激による筋原性反応の起源を球形襄である と推定した。外後頭隆起反応 (6) 8) と VEMP ${ }^{1) \sim 4) ~}$ は，共に強大音刺激により誘発される筋原性反応 であり, 聴力障害の程度に依存せず, 前庭神経切 断術後に消失するなどの共通した特徵を持ってい る。さらに, 最近の基礎的研究から哺乳類でも球 形囊神経が強大音に反応寸ることが明らかとなっ てきた ${ }^{910)}$ 。したがって, VEMP の起源も外後頭 隆起反応と同様に外側半規管ではなく球形囊であ る可能性がある。

第 8 脳神経である内耳神経は顔面神経と共に内 耳道を通り, 内耳道底で蝸牛神経と前庭神経との 2 枝に分かれる。前庭神経は，さらに上前庭神経
A

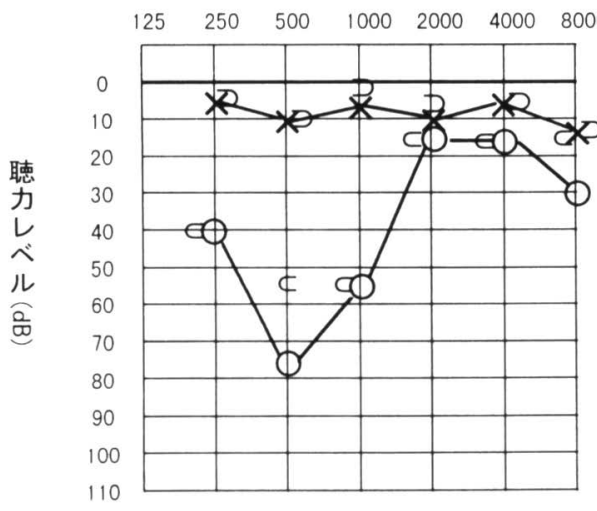

B

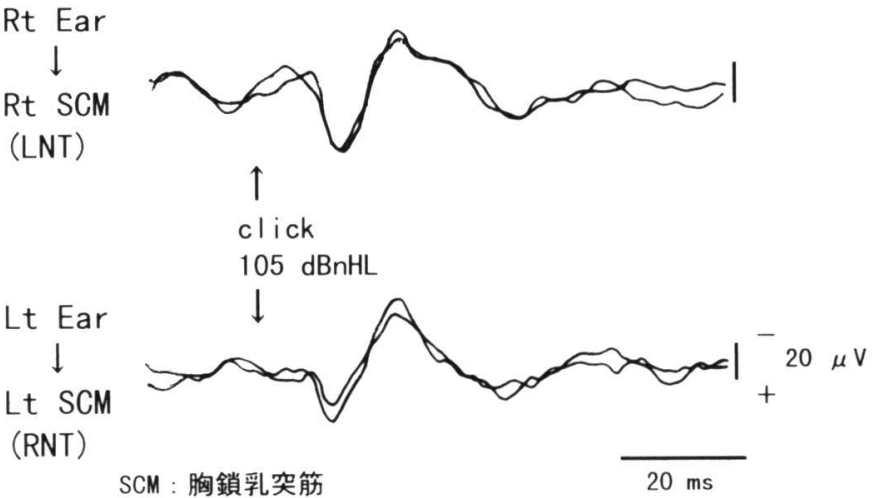

図 4 右聴神経腫瘍症例の VEMP 記録右横の縦線は $20 \mu \mathrm{V}$ の校正。 
A

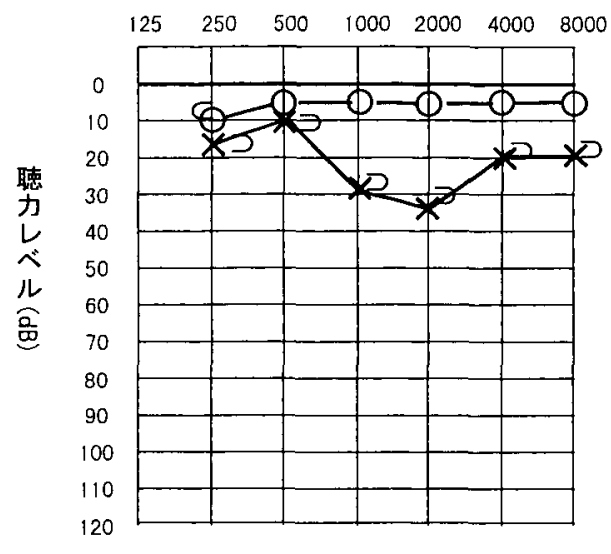

B
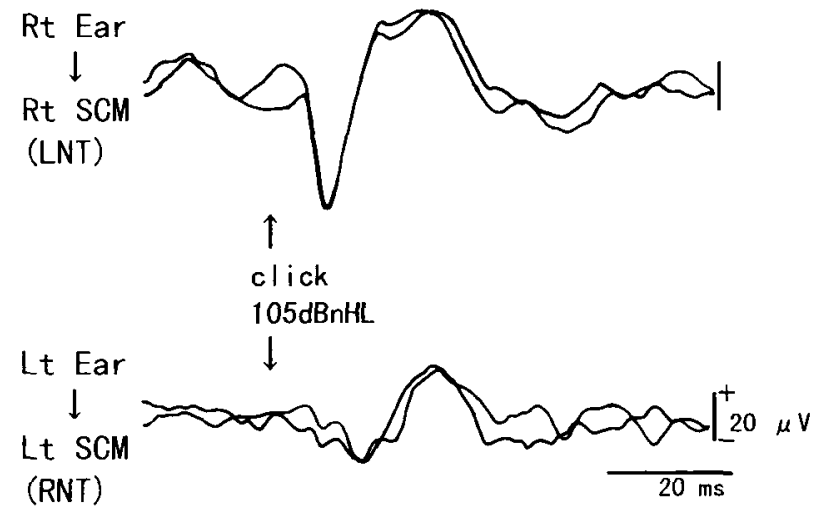

SCM : 胸鎖乳突筋

図 5 左聴神経腫瘍症例の VEMP

と下前庭神経に分けられ，それぞれ外側半規管， 前半規管和よび卵形褧, 後半規管および球形製の 感覚上皮に達する11。したがって，外側半規管機 能を反映する温度眼振反応は上前庭神経を経由す る。本研究に扣いて聴神経腫瘍症例で温度眼振反 応の CP\%と VEMP 反応の間に解離が認められ たことは，VEMP 反応が上前庭神経ではなく， 下前庭神経の機能を評価している可能性を示唆し ている。一方, 前庭神経炎に上る後迷路障害例で の VEMP 反応は Murofushi ら ${ }^{12)} に よ り$ 報告さ れている。彼らは，前庭神経炎患者の経過中に認 められる後半規管型の良性発作性頭位眩軍症 (PSC-BPPV) が VEMP 反応存在例の $32 \%$ に観 察されたが，VEMP 反応消失例では全く観察さ れなかったことを報告した。PSC-BPPVは，理 学療法13) p手術療法14) の治療成績から後半規管 の canalolithiasis 汇よるものと考えられているた め，彼らの報告は後半規管機能を反映する下前庭 神経障害が VEMP 反応の消失の原因であること を示したものとして興味深い。

小松崎 ${ }^{15)}$ は, 聴神経腫瘍の起源として下前庭 神経が最も多く, 上前庭神経, 蝸牛神経の順に頻 度が低くなることを述べている。今後, 比較的頻 度の高い下前庭神経由来の聴神経腫瘍の早期診断 にVEMP が応用され, 球形震一下前庭神経の検 查法としての有用性が明らかとされることが期待
される。

結語

内耳性および後迷路性障害症例への強大クリッ ク音刺激によるVEMP 反応を温度眼振反応の $\mathrm{CP} \%$ と比較した。両者の間には，解離例がみら れ, VEMP 反応が球形襄一下前庭神経系前庭機 能を反映する可能性が示唆された。今後，新たな 前庭機能検査として，種々のめまい疾患を中心に 症例を重わる必要がある。

文献

1) Colebatch JG, Halmagyi GM: Vestibular evoked potentials in human neck muscles before and after unilateral vestibular deafferentation. Neurology 42:1635-1636, 1992

2) Halmagyi GM, Colebatch JG, Curthoys IS: New tests of vestibular function. Baillieres Clin Neurol 3: 485-500, 1994

3 ）將積日出夫, 長崎正男, 安村佐都紀, 他: 音 刺激による胸鎖乳突筋誘発筋電図の検討.

Equilibrium Res 55: 538-544, 1996

4) Colebatch JG, Halmagyi GM: Myogenic potentials generated by a click-evoked vestibulocollic reflex. J Neurol Neurosurg Psychiatry 57: 190-197, 1994

5 ）平衡機能検査の実際. 日本平衡神経科学会 
編. 南山堂, 東京, 1986

6 ) Townsend GL, Cody DT: The averaged inion response evoked by acoustic stimulation: Its relstion to the saccule. Ann Otol Rhinol Laryngol 80: 121-131, 1971

7 ) Bickford RG, Jacobson JL, Cody TR: Nature of average evoked potentials to sound and other stimuli in man. New York Acad Sci 112: 204-218, 1964

8 ) Cody DT, Bickford RG: Averaged evoked myogenic responses in normal man. Laryngoscope 79: 400-416, 1969

9) McCue MP, Guinan Jr J: Acoustically responsive fibers in the vestibular nerve of the cat. J Neurosci 14: 6058-6070, 1994

10) Murofushi T, Curthoys IS, Topple AN, et al: Responses of guinea pig primary vestibular neurons to clicks. Exp Brain Res 103: 174178,1995

11）日本人体解剖学第三巻. 金子丑之助著. 南山
堂, 東京, 1976

12) Murofushi $T$, Halmagyi $M$, Yavor RA, et al: Absent vestibular evoked myogenic potentials in vestibular neurolabyrinthitis. Arch Otolaryngol Head Neck Surg 122: 845-848, 1995

13) Parnes LS, Prince-Jones RG: Particle repositioning maneuver for benign paroxysmal positional vertigo. Ann Otol Rhinol Laryngol 102: 325-331, 1993

14) Parnes LS, McClure LA: Posterior semicircular canal occlusion for intractable benign paroxysmal positional vertigo. Ann Otol Rhinol Laryngol 99: 330-334, 1990

15）小松崎篤 : 内耳道病変の臨床. 東京医学社, 東京, 1987

$\left(\begin{array}{l}\text { 原稿到着: 平成 } 9 \text { 年 } 1 \text { 月 } 27 \text { 日 } \\ \text { 別刷請求先 : 將積日出夫 } \\ \text { 干930-01 富山市杉谷 } 2630 \\ \text { 富山医科薬科大学耳鼻咽侯科学教室 }\end{array}\right)$

